\title{
СУДОЧИНСТВО ТА ПРАВОВИЙ ЗАХИСТ У ГЕТЬМАНЩИНІ
}

\section{БАНДУРКА Сергій - доктор філософії, адвокат АО «Креденс», м. Київ DOI 10.32782/NP.2021.1.6}

\begin{abstract}
Після Переяславськоӥ Ради 1654 року частина українсъких правобережних земель підпадала під юрисдикиію московсъкої влади, зберігаючи певну автономію. Воєводсъко-приказна система російской самодержавної адміністраціӥ намагалася поширити свій вплив на всі сбери суспільного життя Гетьманщзини, зокрема, судочинство, яке московсъка влада хотіла повністю поставити під свій контроль.
\end{abstract}

Фактично на правобережних землях склалося двовладдя - влада гетьмана $і$ влада московсъких воєвод, які очолювали московсъкі гарнізони в окремих украӥнсъких містах на Правобережжі та в м. Києві.

Малоросійсъкому приказу, створеному за рішенням изаря Олексія Михайловича, були підсудні справи, пов'язані із посадовими і службовими особами, приказ тримав під контролем і вище судочинство Гетьманщини.

Проте в умовах московського контролю $i$ обмежень у судовому процесі Гетьманщини в другій половні XVII cm. Формувалася система правового (юридичного)захисту, що є частиною історії становлення $i$ розвитку украӥнсъкої адвокатури.

Ключові слова: адвокатура, правовий захист, суд, позов.

Актуальність дослідження системи правового захисту в судовому процесі часів Гетьманщини (друга половина XVII ст. XVIII ст.) у тому, що цей період є важливим моментом у становленні і розвитку історичної традиції українського державотворення, невід'ємним елементом якого є історія розвитку української адвокатури.

Мета і завдання статті полягають у доцільності дослідження маловивченої теми функціонування правового захисту в Гетьманщині - державному утворенню на правобережних землях України.

Наукова розробленість правового захисту в судовому процесі має місце в працях О.М. Бандурки, В.А. Греченка, К.А. Сафроненко, В.М. Ермолаєва, А.Й. Пашука, Н.П. Василенко, М.С, Скибченко, В.А. Смолія та інших. Вказані вчені зробили значний внесок в дослідження стану правового захисту у судочинстві Гетьманщини, але вивчення історії і теорії Української держави потребує більш детального аналізу правового захисту в судочинстві часів Гетьманщини.

\section{Виклад основного матеріалу}

Українська судова система в другій половині XVII ст. на землях Гетьманщини мала розгалужений характер. На території Гетьманщини одночасно діяла юрисдикція гетьманів, Малоросійського приказу, полкових судів, суди воєвод, козацькі суди, магістерські суди, генеральні суди.

Малоросійським приказом давалася кваліфікація державним злочинам гетьманів, старшини і вищого духовенства, приз спрямовував вищі суди в потрібному йому руслі щодо проведення слідств, винесення вироків, а часто й сам виступав у ролі другої інстанції 3 кримінальних справ, проводив 


\section{Теорія, історія держави і права, конституційне право}

додаткові кримінально-процесуальні дії і виносив остаточне рішення, а потім контролював його виконання. Нерідко зазначена інстанція проводила ці дії без наявності апеляційної скарги в ній. ${ }^{1}$

Суперечності, які виникали між російським воєводами і органами гетьманського управління під час розслідування кримінальних чи інших справ, вирішувалися спільними розслідуваннями, що проводилися представниками гетьмана і Малоросійського приказу, результати якого були підставою для винесення рішень вищим гетьманським судом з цієї справи.

Стосовно справ, що належали до компетенції воєводських суддів України, приказ виступав другою і наглядовою інстанцією 3 кримінальних справ, незважаючи на те, що справи про викрадення жителів України i насильного їх вивезення в Росію розглядалися в першій інстанції. Вироки цих судів, після проведення розслідувань Малоросійським приказом часто змінювалися. ${ }^{2}$

Під юрисдикцію Малоросійського приказу також підпадали справи щодо правопорушень українців на території Росії. ${ }^{3}$ Справи про правопорушення з боку представників російського військово-адміністративного апарату, здійснених на території України, яка входила до компетенції воєвод, розглядалися приказом за російським законодавством, проте бралися до уваги і норми українського як матеріального, так і процесуального права. ${ }^{4}$ У 1667 році царською грамотою було підтверджено заборону воєводам втручатися і розповсюджувати на право Гетьманщини російську юрисдикцію, проте іiі вплив уже мав місце при Б. Хмельницькому. Це проходило методом перенесення справи за проханням процесуальної сторони, яка була незадоволена вироком козацького

\footnotetext{
1 Софроненко К.А. Малороссийский приказ русского государства второй половині XVII и начала XVIII века. М.: Изд-во Моск. ун-та, 1960.С.68-70.

${ }^{2}$ Там само.C.70-73.

${ }^{3}$ Окіншевич $\lambda$. Аекції з історії українського права. Право державне: Доба станового суспільства. (На правах рукопису). Мюнхен: Укр. вільний ун-т, 1947.C.47.

4 Софроненко К.А. Малороссийский приказ русского государства второй половині XVII и начала XVIII века.C.80-82.
}

суду, у суд воєводи. ${ }^{5}$ Міста Гетьманщини, які володіли магдебурзьким правом, прагнули відстояти свою автономію, у тому числі й у судовому праві, перед козацькою і старшинською адміністрацією, часто зверталися за підтримкою безпосередньо до воєвод і царського уряду ${ }^{6}$, що ставало одним із приводів посилення обмежень самостійної діяльності української правової системи.

Судова влада в другій половині XVII ст. хоча і поєднувалася 3 адміністративною, а керівники місцевих органів влади були одночасно й суддями, однак паралельно з ними засідали і професійні судді. Призначення в судові органи здійснювалося за принципом виборності, але не у всіх випадках. Після обрання місцевою громадою треба було пройти ще затвердження на основі апробації вищої влади, тобто гетьмана. Для цього жителі повідомляли спеціальним листом, що бажають бачити зазначену людину на відповідній посаді у судді й просять гетьмана його затвердження, на що він повідомляв своїм універсалом про затвердження на цій посаді і наказував скласти присягу, як того вимагає закон. ${ }^{7}$ Така система вибору суддів через загал населення проіснувала до 1715 року.

Перед тим, як заступати на посаду, суддя складав присягу. Щоправда, на початку існування судової системи Гетьманщини присягу складали тільки ті особи, які не були наділені урядовою владою, а володіли чисто правовою компетенцією, тобто були тільки суддями.

У період гетьманування Б. Хмельницького в Україні фактично існувало водночас три посади генеральних суддів. Формально судді мали рівні повноваження. У дійсності їх становище різнилося - один із суддів підпорядковувався іншому. Це залежало від їх взаємовідносин з гетьманом, походження, віку, терміну перебування на посаді та інших чинників.

\footnotetext{
${ }_{5}^{5}$ Оглоблін О. Україно-московська угода 1654 роки. Нью-Йорк-Торонто: Б.в., 1954.С.43.

${ }^{6}$ Грабовський С. Ставрояні С., Шкляр $\lambda$. Нариси 3 історії українського державотворення. К.: Генеза, 1995.C. 172-173, 202-203.

7 Аазаревский А. Описание старой Малороссии: Материалы для истории заселения, землевладения и управления.Т.2: Полк Нежинский. К.: Тип. К.Н. Милевского, 1893.С. 335, 337.
} 
Клейнодами суддів були «ліска», або «трость суддівська», i «печатка войскова суддейська».

Генеральні судді очолювали колегію генерального суду. Під час виїзних засідань генерального суду до його роботи залучалися полкові судді, сотники, війти та бурмістри. За дорученням гетьмана генеральний суд розглядав різні кримінальні справи та апеляції на рішення нижчих судів. Про хід розгляду справи і винесений вирок судді доповідали гетьманові, який затверджував рішення суду. Незначні кримінальні справи генеральні судді мали право розглядати одноосібно. $^{8}$

Полковий суддя очолював полковий суд і судову канцелярію. Полковий суд розглядав основну масу кримінальних справ. Полковий суддя значною мірою залежав від полковника. Нерідко полковники головували в полковому суді, формували склад судової колегії. Полковий суддя приймав справи до розгляду за рішенням полковника і діяв «по рассказанью пана полковника». ${ }^{9}$

3 середини XVII і на початку XVIII століть на території Гетьманщини слідчі дії в козацьких судах проводили осавули, у міських - слуги, які там несли службу, або інші міські урядовці чи представники міщанства. ${ }^{10}$

Повноваження осавулів в основному визначилося у першій половині XVII ст. За дорученням гетьмана осавули проводили дізнання і попереднє слідство, здійснювали судочинство, наглядали за виконанням судових вироків, виступали у ролі судових виконавців. Іноді попередне слідство могли проводити генеральний писар (за дорученням гетьмана) та хорунжий (за дорученням полковника).

Розгляд кримінальної справи починався 3 наявності потерпілої сторони, яка в судових документах Гетьманщини мала назву «поводовая сторона», «актор», «інстигатор», «жалобливая сторона». Сторона, яка

\footnotetext{
๔рмолаєв В.М., Козаченко А.І.Органи влади і управління Української держави (друга половина XVII - XVIII ст.).C. 85

${ }^{9}$ Там само.C.56.

${ }^{10}$ Пашук А.Й. Суд і судочинство на Лівобережній Україні в XVII-XVIII ст. (1648-1782). C. 110.
}

себе захищала від претензій скаржника, в судово-процесуальних документах мала назву «отпорная», «злодейская», «отводна», «позвана». Процесуальну правоздатність за принципами юридичного процесу визнавали за всіма громадянами. Проте судові чи процесуальні органи у своїй практиці опиралися на Литовський Статут, «Саксон» i «Порядок», де вказувалося на осіб, які не мали процесуальної правоздатності,- до них відносилися невільники, «баніти», «безчесні», «прокляті». Водночас не всі ті, які мали процесуальну правоздатність, могли бути процесуально дієздатними, тобто мати можливість виступати у процесі безпосередньо від власного імені. Ї̈̈ не мали неповнолітні, жінки, піддані, розумово хворі, марнотратники, глухі, німі; повнолітніми виступали чоловіки після 18 років, а жінки - після 14 років. В окремих постановах зустрічаємо, що жінок вважали повнолітніми вже після 13 років. Раніше жінка могла ставати повнолітньою, якщо вона вийшла заміж. Проте й тоді вона не мала права на процесуальну дієздатність і в процесі могла виступати, як і в польському праві, ${ }^{11}$ під захистом опікуна. ${ }^{12}$

Опікуном малолітніх, як правило, у процесі виступав батько. Коли опікуна не було, його призначали серед адвокатів. Правові інтереси жінок захищали опікуни, якими для незаміжніх дівчат був батько для заручених - батько, або наречений, а для заміжніх - чоловік. Право останнього виступати захисником своєї дружини було настільки сильним, що від нього не вимагалося доводити свою правоздатність. Серед жінок за своїм сімейно-родовим станом тільки вдова мала право процесуальної дієздатності. Вона могла брати участь у процесі не тільки від свого імені, але й від імені дітей, як їх законного опікуна, якщо суд не відібрав iї опікунства над сиротами. Інтереси підданих виражав їх пан або орендатор. Розумово хворих, серед яких розрізняли «ума лишених» $\mathrm{i}$ «природних дураків», а також марнотратників (їх часто називали ще «суєтратними людьми») заступали опікуни або курато-

\footnotetext{
11 Dobkowski P. Prawo prywatne polskie.Lwow, 1910.T.I.S.208.

${ }^{12}$ Акты Ю3Р.T.12. С.194.
} 


\section{Теорія, історія держави і права, конституційне право}

ри. ${ }^{13}$ Це відбувалося теж і з німими, глухими i від народження сліпими. Незважаючи на ті соціальні обмеження, неповнолітні користувалися певними пільгами. До настання повноліття їх не мали права вільно позивати на процес чи допитувати, а на випадок ïх оскарження другою стороною вони без шкоди для себе і покарання могли не брати участі в розправі.

У часи Гетьманщини на території українських земель продовжували діяти Аитовські статути та Магдебурзьке право. Однак через свою чужорідність вони не могли заповнити правове поле, й тому в першій половині XVIII ст. розпочалася кодифікація українського права. Особливого значення набув перший кодекс українського права 1743 року - «Права, по которым судится малороссийский народ». У Кодексі українського права 1743 року вперше вжито слово «адвокат» у значенні «захисник прав сторони». Адвокатами могли бути повнолітні, християнської віри, розумово й фізично повноцінні, світського стану чоловіки. Повноваження в суді адвокат підтверджував документом, виданим клієнтом. Праця адвоката була платною, але були випадки, коли адвокат виконував свої обов'язки безоплатно. За порушення обов'язків до адвоката застосовувалися санкції, включно до вилучення із списку адвокатів .

У другій половині XVII століття зрідка трапляються згадки про офіційного представника, який захищає сторону під час проведення процесуальних дій чи судового розгляду справи. В основному це були представники опікунів в інтересах підопічних, а батьків - в інтересах дітей.

На території Гетьманщини, на відміну від західного права, публічного обвинувача, який повинен бути неодмінним учасником процесу, не було. У матеріалах кримінально-процесуальної та судової практики трапляється приватний обвинувач, якого називали інстигатор. Це ще раз підтверджує думку про це, що кримінально-процесуальні дії та й сам судовий процес у кримінальних справах мав приватно-правовий характер. В актових документах фіксуються випадки,

\footnotetext{
${ }^{13}$ Акты ЮЗР.Т.13.:1677-1678. СПб.: Тип. А.М. Кото-
} мина, 1885.C.196. коли функції обвинувача виконує представник від гетьмана. Проте він брав участь у справах особливої ваги, або політичних, наприклад, про державну зраду чи замах на представників місцевого чи генерального уряду. Зазначена офіційна особа виступала з обвинуваченням у конкретній справі, і в іiі юридичну компетенцію не входили прокурорські функції.

Початковою стадією кримінального процесу в судочинстві Гетьманщини було порушення кримінальної справи. Уцей час сторона мала право диспозитивності, що виражалося у формі оскарження. Вирішення питання про початок судової справи майже завжди залежало від зацікавленої сторони. Кримінально-процесуальна дія, яка переходила в судовий процес, починалася тільки на вимогу потерпілої сторони.

Кримінальні або цивільні справи заводилися після подання позову або позовної скарги, якому надавалося великого значення - «позов всего судового поступка фундамент». У часи Гетьманщини у значення позову входили два окремі заходи: 1) перший, пов'язаний із внесенням до суду скарги 3 метою розпочати слідство, званої також «жалоба», «жалобливая супліка», «челобитна», «явочное челобитье»або «челобитье», «доношение»; 2) захід надсилання із суду до оскарженого листа із викликом на розправу; цей вид документа називали «позовний указ», «позоний лист», «позов», де так само вказувався термін виклику в суд.

Перед внесенням позову позовник повинен був виконати окремі процесуальні заходи. Передусім потрібно було попередити оскарженого про задум розпочати справу. Ця дія відбувалася з метою мирного врегулювання спору без судового втручання. Форма і зміст нагадування були довільними. Позовник протилежну сторону міг повідомляти сам або через третю особу. Нагадування було в передпроцесуальній дії і мало чисто факультативний характер, тому його відсутність не могла впливати на проведення процесуальної дії і в подальшому судового розгляду. Але обов'язковим був протест як форма скарги стосовно порушення кримінально-процесуальної дії 
чи судового процесу. Сторона, яка внесла позов, зобов'язана спочатку факт порушення у вигляді протесту записати в урядову актову книгу, засвідчити сторонніми людьми ознаки насилля і викликати у вказаний термін самого кривдника. ${ }^{14}$ Цей протест подавався у суд за місцем його територіально-адміністративного розміщення або за місцем скоєння злочину.

Перед тим, як внести позов, скривджений звертався до місцевого уряду з вимогою забезпечити його - через проведення попереднього слідства - доказами, на які він міг спиратися під час проведення процесу. Така процедура фіксується в актових документах Чернігівської полкової канцелярії, де протестував бунчуковий товариш Яків Полуботок проти прикажчика Чернігівської катедри ченця Атазія, який побив його челядь під час наїзду на маєток першого: «... прошу да благоволить полковая Черньговская Канцелярія бой и знаки боевіе, в подданих моих имьючиеся приказать описать и сию мою протьстацию приказать, приняв в книги записать, а исковая челобитная, где подлежит, подана будът». ${ }^{15}$

Після проведення передпроцесуальних дій потерпілий віддавав судові на розгляд справу про суперечку. Кримінально-процесуальні дії судового органу починалися 3 розгляду чолобитної або скарги. Писар записував подання скарги, яку приймав особисто, присвоював їй порядкове число та вносив у судову книгу.

Письмові позови подавалися в усіх важливих процесуальних справах. Це стосується і магістратських судів, які проводили кримінально-процесуальні дії та процеси за магдебурзьким правом. Так, в одній із процесуальних справ, яку розглядав магістратський уряд, фіксується постанова, де вказується на те, що у позовах проти місцевих людей вживається, як правило, усна форма, але в дійсності все вирішує суддя, бо «остаеться на воль судіи позвать кого словесно или письменно, кромь важных случаев, в

\footnotetext{
${ }^{14}$ Василенко Н.П. Матеріали до історії українського права. С.76.

${ }^{15}$ Слабченко М.Е. Малорусский полк в административном отношении: ист.-юрид. очерк. Одесса: Техник, 1909.C.349.
}

коих письменной позов надобен». ${ }^{16}$ Суди, що проводили процесуальні дії та розглядали справи за магдебурзьким правом, мали п’ять видів позовів: а) усний, або словесний; б) писемний; в) публічний на тих позивачів, що переховуються від кримінальної відповідальності; г) через оголошення на базарі чи на вулиці; д) у кримінальних справах, коли суддя наказує відразу арештувати позванного.

Диспозитивність обмежувалася у тих випадках, коли справа торкалася кримінально-процесуальних дій, а також коли позовник у позові зневажав честь оскарженого або покладався на свідків, які мали підтвердити скоєння злочину оскарженим, чи коли позовник після подання позову напав на оскарженого, щоб влаштувати самосуд. Тоді розправа мала відбутися, хоч і позовник відкликав свій позов.

На початковому етапі ведення кримінально-процесуальної дії переважно відносилося до компетенції судів першої інстанції і попереднє слідство не було обов'язковим у кримінальному судочинстві. Це пояснюеться принципом зазначеного процесу, що на початку доби Гетьманщини судовий процес мав приватно-правовий характер і основну роль у кримінальній справі відігравав сам позивач-потерпілий. Перш ніж представити позов-скаргу в судовий орган, потерпілий повинен провести ряд дій, які мали ознаки попереднього слідства.

У деяких судових документах слідчі дії називалися «шлякуванням». ${ }^{17}$ Коли «шлякування» давало позитивні результати і нападали на слід злочинця, за ним встановлювалася «погоня» («гоніння сліду»). Коли потерпілий натрапляв на слід, який вів до іншого двору, то тоді він за допомогою представників сільської управи (переважно це були староста або отаман) проводив обшук підозрюваного; були випадки, що проводили обшук у цілому селі.

У процесі досліджуваного періоду було два типи термінів («сроків»): термін зви-

\footnotetext{
${ }^{16}$ Василенко Н.П. Матеріали до історії українського права.С.198.

17 Отрывки из Нежинских магистратских книг 1657-1674 годов. [под ред. А.Аазаревского. Чернигов: Типография губернского правления, 1887.С54.
} 


\section{Теорія, історія держави і права, конституційне право}

чайний або зазначений і термін «завитий», званий ще «крайнеположений» або «убивающий».

Перший термін був менш важливий i застосовувався у всіх справах, для яких не був застережений завитий термін. Проте 3 часом суди прямували до прискореного судового процесу і того ж вимагали під час проведення кримінально-процесуальних дій від компетентних органів, і зазначений термін почав уживатися все рідше. У зв’язку 3 цим дедалі частіше почав входити в практику «завитий» термін, з часом він стає звичайною процесуальною процедурою. Усе це пояснюється тим, що за неявку на звичайному терміні не було значних і відповідальних наслідків, на відміну неявки на завитому терміні, через це тим моментом користувалися та дозволяли у власних інтересах зволікати спір і не прибувати у визначені терміни. Неявка на звичайному терміні стороні обходилася в поверненні видатків протилежній стороні, грошовому покаранні на користь судового органу і покаранні через арешт, але не було загрози, пов'язаної з програшем справи. ${ }^{18}$

Викликаний мав право домагатися, щоб виклик чи повістку йому було вручено за тиждень до початку судового процесу, а якщо позов залишено вдома в момент, коли не було оскарженого, - то навіть за шість тижнів. Проте із цієї загальної норми були винятки. Коли позовник мешкав за місцем знаходження суду, то його можна було викликати на розправу усним позовом, і тоді він був зобов'язаний негайно прибути до суду. ${ }^{19}$

Слідчі дії суду розпочиналися після того, як потерпіла сторона, провівши всі процесуальні заходи, пов'язані з попереднім розслідуванням, подавала в суд письмову позов-скаргу.

Суд нижчої інстанції проводив слідство в кримінальних справах, які остаточно подавалися для розгляду у вищу судову установу, що на своєму засіданні апробував ці слідчі

\footnotetext{
${ }_{18}$ Василенко М. Матеріали до історії українського права.С.95-96.

19 Шамрай С. Боротьба козаків Київської сотні 3 київськими монастирями та магістратом у XVII XVIII в.C.92.
}

діï. ${ }^{20} \mathrm{~B}$ актових документах зазначеного періоду фіксуються випадки, коли вищий суд, розслідувавши справу, надсилав відповідну атестацію нижчому судові.

Для початку проведення судового слідства потрібна офіційна ухвала цього органу. Після чого представники від суду чи місцевого органу управління оглядали місце злочину. 3 метою виявлення речового доказу в судовій практиці часто використовувався обшук або трус, як і в попередньому слідстві. Для організації такого заходу залучалися суд у повному складі і представники місцевої влади. До обшуку залучався також потерпілий i його довірені особи або родичі. При відсутності злочинця суд давав на «прослух». ${ }^{21}$

Суди до обвинувачуваних використовували запобіжні заходи у формі попереднього затримування. Їх тримали під вартою в острогах, в'язницях або «секвестрах», як тоді називалися місця ув'язнення, де перебувало чимало колодників та колодниць.

В окремих міських судах для утримування підозрілих у скоєнні кримінальних злочинів використовувалася спеціальна тюрма, так зване «тверде везеня».

у досліджуваний період суд вимагав поруки від позовників. Це відбувалося при умові, коли неосілий позовник подавав скаргу на осілого. Тоді суд при порушенні позовництва був зобов'язаний «с таких челобитчиков брать же сказки с подкрьплением о не съезде 3 суда». ${ }^{22}$

Важливою стадією процесу був розгляд справи у судовому засіданні. Судочинство характеризувалося формалізмом, здійснювалося в основному на латині.

3 початком правління московського царя Петра I боротьба з українською автономією значно посилилась. ${ }^{23}$ Підтвердженням цьо-

\footnotetext{
20 Актовые книги Полтавского городового уряда XVII-го века: Справы поточныя 1664-1671 годов.С.119.

${ }^{21}$ Актовая книга Стародубского городового уряда 1693 года / [под ред. В.А. Модзалевского]. Чернигов: Изд-во Черниговской губернской ученой архивной комиссии, 1914.С.68.

22 Стороженки. Фамильный архив. Книги третие мьскіе Ператинскіе, споряженіе в р. 1683 мьсяця июня, осмого надесять дня.С.638.

${ }^{23}$ Греченко В.А. Історія та культура України.Харків: ХНУВС,2017.С.117-118.
} 
го є створення I Малоросійської Колегії і затвердження посади російського резидента при гетьмані $з$ метою контролю за діяльністю його правління. Крім того, у функції зазначеної інституції входило проведення спільних зі старшиною розслідувань, судових процесів і отримання відомостей про внутрішню обстановку в Україні, ${ }^{24}$ перешкоджання гетьманському судові у винесенні неузгоджених 3 царем смертних вироків стосовно полковників, полкової та генеральної старшини, а також розслідування політичних справ. Стосовно останньої функції, то прикладом цьому є слідча справа українського селянина Данила Білоконника, обвинуваченого у неповазі до царя Петра I, яка була відкрита в Малоросійській колегії у м. Глухів. ${ }^{25}$

Часті обвинувачення в неправосудності та зловживанні від представників різних верств населення Гетьманщини спрямовувалися і на адресу Генерального суду. Скарги на непорядки в судах доходили до гетьмана, а потім і до царя. ${ }^{26}$

Таке становище судової системи Гетьманщини було лише на руку Петру I і стало приводом для обмеження автономії в адміністративно-судовій діяльності урядових органів України. За таких умов і Малоросійська колегія мала презентувати самодержавство у свідомості рядових козаків і посполитих як орган, що захищає їх інтереси від свавілля старшини відповідно за справедливістю і законом. ${ }^{27}$

В автономістських колах української старшини ставлення до російської політики проявлялося пасивним супротивом. Особливо це виявилося під час правління гетьмана П. Полуботка. Почалося саботування діяльності I Малоросійської колегії, зміцнення законності слідчих і судових органів, а також усієї судової системи Гетьманщини. Цими заходами Полуботок хотів забезпечити гетьманську державність підтримкою

\footnotetext{
24 Яковлів А. Українсько-московські договори в XVII-XVIII віках. Праці українського наукового інституту.Кн.3. Варшава, 1934. Т.XIX.С.142.

25 Дубинянский М. В застенках тайной канцелярии. Зеркало недели. 2001. 22 сентября (№37).

26 Лазаревський А. Павел Полуботок. Русский Архив. М., 1880. Кн. 1. С.150.

27 Шевчук В.Л. Козацька держава. Етюди до українського державотворення. К.: АБРИС, 1995.С.239.
}

соціальних низів, що на той час становила більшість українського народу. ${ }^{28}$

Так, своїми першими універсалами від 19 листопада 1722 р. П.Полуботок забороняв старшині залучати козаків до робіт у себе і знімати з них наклади в судах, чим він майже на місяць випередив указ I Малоросійської колегії від 17 серпня 1722 р. ${ }^{29}$

Одним із значних універсалів, що стосувалися реформування судів, у тому числі й органів, що займалися процесуальними діями, був універсал, виданий Полуботком 19 серпня 1722 р. У ньому вказувалося на необхідність встановлення колегіальності судочинства, залучення до розгляду справ, крім урядовців, й інших чесних і розумних осіб 3 позитивною в суспільстві репутацією. ${ }^{30}$ Для проведення слідчих дій і судових засідань потрібно створювати спеціальні судові приміщення, в яких мали зберігатися юридичні кодекси і збірники, розміщуватися судовий персонал, крім цього передбачалися спеціальні приміщення для попереднього затримання осіб, котрі перебували під слідством. ${ }^{31}$ Судова колегія повинна була проводити судове слідство і розглядати справи відповідно до принципів колегіальності, справедливості, законності, об’єктивності, доцільності. ${ }^{32}$ Особливо це стосувалося сільських судів, де попередне розслідування і судові засідання супроводжувалися публічними хабарами і здирствами війтів та отаманів. Через це, під страхом як матеріальних, так і тілесних покарань, вимагалося проводити юридичні дії у відповідних місцях і судити «не пьянственным, но трезвым умом».33

У цей час усі важливі кримінальні та цивільні справи розглядалися фактично вже за участі адвокатів.

\footnotetext{
28 Там само.

${ }^{29}$ Василенко М. Як скасовано Аитовського Статута (з історії кодифікації західно-руського та вкраїнського права) Зап. соц.-екон. відділу ВУАН. Т. 2-3. К., 1926.C. 39-40.

${ }^{30}$ Лазаревський А. Суды в старой Малороссии.С.90. 31 Дядиченко В.А. Нариси суспільно-політичного устрою Аівобережної України кінця XVII-початку XVIII ст.C.345.

32 Лазаревский А. Отрывки из дневника гетманской канцелярии за 1722-1723 годы.С.7-8

33 Василенко М. Як скасовано Аитовського Статута.С.91
} 


\section{Теорія, історія держави і права, конституційне право}

Як зауважує Віктор Брехуненко, ${ }^{34}$ поява та розвиток адвокатських практик у Гетьманщині стало цілком закономірним та навіть неминучим явищем. Випливало це як із природи самої ранньомодерної української держави, так i із логіки розвитку українського судочинства загалом, розпочинаючи з XVI ст. Адвокатська діяльність у Гетьманщині постала на перетині успадкованої старовини та провадження новацій, переданих радикальними змінами в суспільстві, принесеними відновленням української державності. Надзвичайна розвинутість в Україні адвокатури в другій половині XVI століття виконала роль фундаменту для існування та еволюції адвокатських практик Гетьманщини.

\section{Висновок}

У часи Гетьманщини (друга половина XVII - кінець XVIII ст.) на землях, які знаходилися під ії юрисдикцією, діяла розвинута судова система. Саме у сфері судової діяльності Гетьманщини виникли перші паростки адвокатури як форма правового захисту на правобережних українських землях. Правовий захист у судочинстві носив різні форми: представництва, опікунства, змагальності, виконання обов'язків із захисту за дорученням.

Судовий розгляд кримінальних і цивільних справ у Гетьманщині зазнав значного впливу від гетьмана, Малоросійського приказу, від полкової адміністрації і московських воєвод. Але судочинство навіть за таких умов здійснювалося за певним процесуальним порядком за наявності звернення потерпілої чи зацікавленої сторони, при представленні доказів, заслуховуванні сторін, відповідності нормативно-правовим актам, що є вже формою правового захисту.

Адвокатура України в період Гетьманщини була вже визнаною як окремий, соціальний стан, хоч і не була об'єднаною професійною організацією.

\footnotetext{
${ }_{34}^{34}$ Брехуненко Віктор Адвокатський хліб: заробітки адвокатів у Гетьманщині . Київські історичні студії // Науковий журнал № 1 (4). - 2017. - С. 60.
}

\section{Лiтература}

1. Брехуненко Віктор Адвокатський хліб: заробітки адвокатів у Гетьманщині. Київські історичні студії // Науковий журнал № 1 (4). - 2017. - С. 60.

2. Василенко М. Як скасовано Аитовського Статута (з історії кодифікації західноруського та вкраїнського права) Зап. соц.екон. відділу ВУАН. Т. 2-3. К., 1926.С. 3940.

3. Василенко М. Як скасовано Аитовського Статута.С.91

4. Василенко Н.П. Матеріали до історії українського права.С.198.

5. Грабовський С. Ставрояні С., Шкляр $\mathcal{\lambda}$. Нариси з історії українського державотворення. К.: Генеза, 1995.С. 172-173, 202-203.

6. Греченко В.А. Історія та культура України. Харків: ХНУВС,2017.С.117-118.

7. Дубинянский М. В застенках тайной канцелярии. Зеркало недели. 2001. 22 сентября (№37).

8. Дядиченко В.А. Нариси суспільнополітичного устрою Аівобережної України кінця XVII-початку XVIII ст.C.345.

9. Ермолаєв В.М., Козаченко A.I.Органи влади і управління Української держави (друга половина XVII - XVIII ст.).С. 85

10. Аазаревский А. Описание старой Малороссии: Материалы для истории заселения, землевладения и управления.Т.2: Полк Нежинский. К.: Тип. К.Н. Милевского, 1893.С. 335, 337.

11. Аазаревский А. Отрывки из дневника гетманской канцелярии за 1722-1723 годы.С.7-8.

12. Аазаревський А. Павел Полуботок. Русский Архив. М., 1880. Кн. 1. С.150.

13. Аазаревський А. Суды в старой Малороссии.С.90.

14. Оглоблін О. Україно-московська угода 1654 роки. Нью-Йорк-Торонто: Б.в., 1954.C.43.

15. Окіншевич $\lambda$. Аекції з історії українського права. Право державне: Доба станового суспільства. (На правах рукопису). Мюнхен: Укр. вільний ун-т, 1947.С.47.

16. Отрывки из Нежинских магистратских книг 1657-1674 годов. [под ред. 
А.Аазаревского.Чернигов: Типография губернского правления, 1887.С54.

17. Пашук А.Й. Суд і судочинство на 入івобережній Україні в XVII-XVIII ст. (1648-1782). С. 110.

18. Слабченко М.Е. Малорусский полк в административном отношении: ист.-юрид. очерк. Одесса: Техник, 1909.C.349.

19. Софроненко К.А. Малороссийский приказ русского государства второй половині XVII и начала XVIII века.С. 80- 82.

20. Стороженки. Фамильный архив. Книги третие мьскіе Ператинскіе, споряженіе в р. 1683 мьсяця июня, осмого надесять дня.С.638.

21. Шамрай С. Боротьба козаків Київської сотні з київськими монастирями та магістратом у XVII - XVIII в.C.92.

22. Шевчук В.Л. Козацька держава. Етюди до українського державотворення. К.: АБРИС, 1995.С.239.

23. Яковлів А. Українсько-московські договори в XVII-XVIII віках. Праці українського наукового інституту.Кн.3. Варшава, 1934. Т.XIX.C.142.

24. Актовая книга Стародубского городового уряда 1693 года / [под ред. В.А. Модзалевского]. Чернигов: Изд-во Черниговской губернской ученой архивной комиссии, 1914.С.68.

25. Актовые книги Полтавского городового уряда XVII-го века: Справы поточныя 1664-1671 годов.С.119.
After the Pereyaslav Rada in 1654, part of the Ukrainian right-bank lands was signed under the jurisdiction of the Moscow authorities, retaining some autonomy.

The voivodship-command system of Russian autocratic administration tried to extend its influence to all spheres of public life. Hetmanate, in particular, the judiciary, which the Moscow authorities wanted to control completely.

In fact, on the right-bank lands there was a dual power of the hetman and the power of the Moscow voivodes, who headed the Moscow garrisons in some Ukrainian cities on the Right Bank and in Kyiv.

The Malorosian order, created by the decision of Tsar Alexei, had jurisdiction over cases involving officials, and the order also controlled the higher judiciary of the Hetmanate.

However, in the conditions of Moscow control and restrictions in the trial, the Hetmanate in the second half of the XVII century was formed by a system of legal (lawful) protection, which is a part of the history of formation and development of the Ukrainian Bar.

Key words: advocacy, legal protection, judicature, litigation.

26. Акты ЮЗР.Т.12. С.194.

27. Акты ЮЗР.Т.13.:1677-1678. СПб.: Тип. А.М. Котомина, 1885.С.196.

28. Dobkowski P. Prawo prywatne polskie. Lwow, 1910.T.I.S.208. 